\author{
Dana KUBÁTOVÁ ${ }^{1}$ \\ Martin MELICHAR ${ }^{2}$ \\ Jan KUTLWAŠER ${ }^{3}$
}

\title{
SOFTWARE FILTERS OF SURFACE ROUGHNESS
}

\begin{abstract}
The aim of this article is to present the system of roughness measurement, the problem of data filtering and processing the results. At the beginning of this article three basic elements of the surface are defined: roughness, waviness and surface shape. When measuring roughness all of these three parts are scanned together and under evaluation they need to be separated. Filtration is possible using roughness measurement systems and software filters. Next part of the article is focused on a description of problems of hardware filtering of these three surface components. Software data filtering description follows the description of hardware filtering. The description of the software filter contains the basic mathematical definition of the filters and their known area of usage and their limitations
\end{abstract}

Keywords: roughness, waviness and shape of the surface area, hardware and software filters

\section{Introduction}

Measurement and evaluation of surface texture represents a major qualitative advance in recent years. Leading producers of measuring instruments (Hommel, Carl Zeiss, and others) respond actively to new requirements. The evolution of measuring instruments is determined by the technical needs of their users as well as by their financial strength. Surface texture is frequently checked by means of single-purpose measuring instruments. For this reason, some of the key producers who put pressure on developing standards related to evaluating the quality of measurement of machined surfaces are the manufacturers of such instruments themselves [2].

This complex evolution has ultimately led to improved technologies of existing tools for surface texture measurement and analysis, as well as to better methods, measuring systems and the system of assessment and evaluation of surface texture that are still under development [7]. The system of assessment and

\footnotetext{
${ }^{1}$ Autor do korespondencji/corresponding author: Dana Kubátová, University of West Bohemia in Pilsen, Univerzitní 8, 30100 Plzeň, Czech Republic, e-mail: kubatova@rti.zcu.cz

${ }^{2}$ Martin Melichar, University of West Bohemia in Pilsen, Czech Republic, e-mail: mech@rti.zcu.cz

${ }^{3}$ Jan Kutlwašer, University of West Bohemia in Pilsen, Czech Republic, e-mail: kutlis@rti.zcu.cz
} 
evaluation of surface texture is defined by a body of standards which describe designations, measurement, and evaluation of surface texture, calibration of measuring instruments, and other aspects. They are so-called GPS standards which set out geometrical product specifications [5]. However, the orientation in many new standards and manuals that have emerged over the last few years is very difficult. And when measuring roughness, a lot of companies use measuring applications that are not optimal. These findings have led to the creation of this article with a brief summary of the filters, including references to relevant GPS standards.

Generally, the measurement and assessment of surface texture represent a separate field of metrology. Using special techniques, the data required for characterizing the quality of surface can be obtained. The following questions arise: What is in fact the surface of a part and what are its properties? What determines these properties? What parameters are used to identify such information and under what conditions are they evaluated? These are the aspects are dealt with in the measurement of surface roughness.

\section{Origins}

Surface roughness plays a decisive role in the properties and behaviour of parts in service. It also affects the life and functional performance of parts and therefore the development of measuring technology and metrology of surface integrity is receiving ever greater attention [4]. To obtain an objective evaluation of the quality of surface, an ever greater number of parameters are used which provide relevant information about the surface under measurement. This information, however, must be extracted, i.e. filtered, from the surface in the course of measurement because the surface is the entire collection of irregularities (roughness, waviness, form) which constitute the surface texture (Fig. 1). These irregularities differ in their spacing and their impact on the functional performance of the surface. This is why they must be separated for analysis. Components of the surface texture are separated by filtering. In order to determine specific roughness parameters ( $\mathrm{Ra}, \mathrm{Rz}, \mathrm{Pt}$ and others) from the measured profile (primary profile), the roughness component must be separated from other types of irregularities found in the surface.

It is a collection of relatively closely-spaced surface irregularities which are inevitably created during or as a consequence of manufacture. The most important elements in this creation include the cutting speed, feed, the shape and wear of the tool, and others. However, roughness does not include surface flaws, i.e. irregular random rare irregularities (scratches, cracks, dents, and others) which arise from defects in the material, damage by external forces, and others. It is an irregularity of a larger size onto which roughness is superimposed. It results from the machine tool acting on the work piece, e.g. vibration, insufficient stiffness, imprecise fit, and others [8]. This is the real surface after removing roughness and 
waviness. Errors may be caused by heat, low stiffness, poor adhesion of slide ways, and other factors.

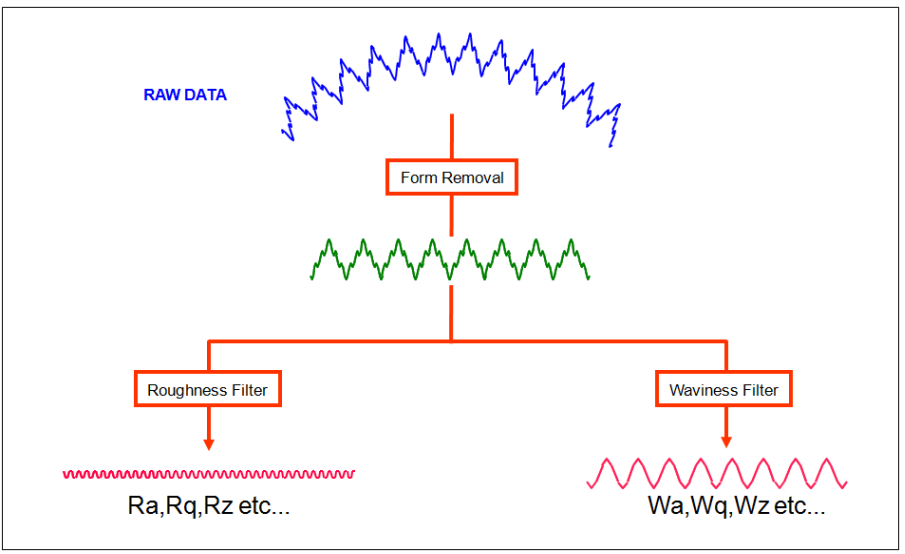

Fig. 1. Surface components

\section{Data filtering system}

The surface roughness measurement system encompasses two processing stages. The first stage involves taking the surface profile of the product by means of a transducer attached to the surface roughness tester. That is, obtaining raw data (primary profile). The second stage consists of processing this profile. The profile processing stage can be split into two parts. One comprises hardwarebased filtering (indicated by the red rectangle) and the other software filtering (blue rectangle).

When processing raw data, it is necessary to proceed in the order, in the first step is used a hardware filter for characteristics (shape, waviness, roughness) to be evaluated. This is followed by a software filter application, in which the choices intersect with the output parameters. The implementation of the filters used is shown in Fig. 2. The application should be always followed from left to right when applying filters as show in Fig. 2. In the first step hardware filters are always used and in the next step software filters are used. This is the basic and rudimentary filtering according to ISO standards. The basic features of the instrument are sufficient for this purpose and no additional machine equipment is needed.

A profile filter is at the basis of measurement of surface texture parameters. It affects the measured values to a great extent. The purpose of this filter is to separate shortwave and long wave components from the profile and remove those wavelengths which are above or below a given frequency [5]. These filters have the same transmission characteristics but different cut-off wavelengths. They transform the profile by removing irregularities with large spacings, e.g. waviness 
or other form errors, which would distort the roughness measurement. To ensure correct output from these filters, one has to identify the sampling length by which the data from the surface under examination is to be filtered. The profile filter splits profiles into longwave and shortwave components.

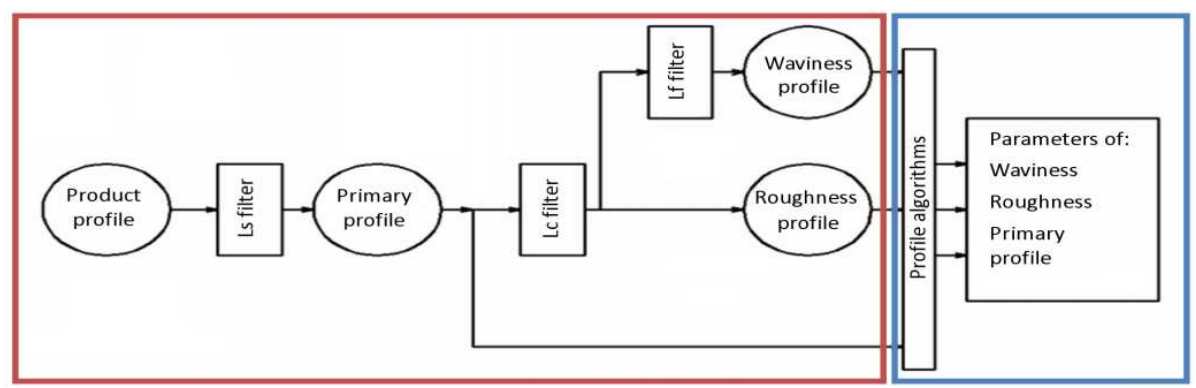

Fig. 2. Surface roughness processing system

While measuring surface texture values, one should take account of the conditions prescribed by standards. It is the relationship between the standardized stylus tip radius $r_{\text {tip }}$ and the ratio of roughness cut-off wavelengths $\lambda \mathrm{c} / \lambda \mathrm{s}$. It is the focus of the ČSN EN ISO 3274 standard [5] (Table 1).

Profile filter $-\lambda c-$, Filter which defines the intersection between the roughness and the even shorter wave components present in a surface".

Profile filter $-\lambda s-$,Filter which defines the intersection between the roughness and waviness components".

Profile filter $-\lambda f-$,Filter which defines the intersection between the waviness and the even longer wave components present in a surface".

Figure 3 shows the filtered lengths of the individual hardware filters to each other.

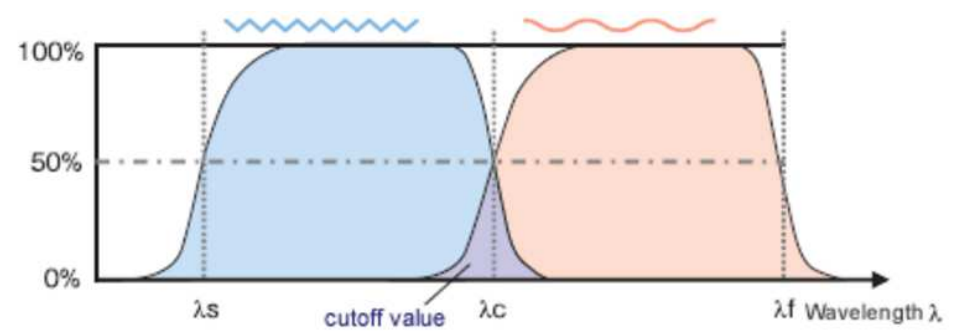

Fig. 3. Hardware-based filters of surface roughness

Software filters follow after the hardware-based filters of surface roughness. With software filters, one can obtain the values of particular surface roughness parameters. According to the ČSN EN ISO 16610-1:2015 standard, these filters 
are divided into two basic groups: 2D and 3D profile filters. Both types of software filters comprise further sub-groups according to the mathematical procedure used:

- Linear profile filters - ČSN EN ISO 16 610-20,

- Morphological profile filters - ČSN EN ISO 16 610-40,

- Robust profile filters - ČSN EN ISO 16 610-30 [9].

Table 1. Classification of filters according to 16610-1

\begin{tabular}{|c|c|c|c|c|c|}
\hline $\begin{array}{l}\text { Filter } \\
\text { type }\end{array}$ & Category & Symbol & Designation & Name & $\begin{array}{c}\text { ISO } \\
\text { standard }\end{array}$ \\
\hline \multirow{11}{*}{ FP } & \multirow{3}{*}{ FPL } & $\mathrm{G}$ & FPLG & Gaussian & $16610-21$ \\
\hline & & $\mathrm{S}$ & FPLS & Spline & $16610-22$ \\
\hline & & SW & FPLSW & Spline wavelet & $16610-29$ \\
\hline & \multirow{6}{*}{ FPM } & $\mathrm{CD}$ & FPMCD & Closed disk & $16610-41$ \\
\hline & & $\mathrm{CH}$ & FPMCH & $\begin{array}{c}\text { Closed horizontal line- } \\
\text { segment }\end{array}$ & $16610-41$ \\
\hline & & OD & FPMOD & Open disk & $16610-41$ \\
\hline & & $\mathrm{OH}$ & FPMOH & $\begin{array}{l}\text { Open horizontal line- } \\
\text { segment }\end{array}$ & $16610-41$ \\
\hline & & $\mathrm{AD}$ & FPMAD & Alternating sequence & $16610-49$ \\
\hline & & $\mathrm{AH}$ & FPMAH & $\begin{array}{l}\text { Alternating sequence } \\
\text { of horizontal segments }\end{array}$ & $16610-49$ \\
\hline & \multirow{2}{*}{ FPR } & G & FPRG & Gaussian & 16610-31 \\
\hline & & $\mathrm{S}$ & FPRS & Spline & $16610-32$ \\
\hline & FP & $2 \mathrm{RC}$ & FP2RC & $2 \mathrm{RC}$ & 3274 \\
\hline
\end{tabular}

Literature sources differ in classifying this filter. It is not clear whether it belongs to mechanical (hardware-based) filters or software filters. Why should it be discussed here then? It is mainly because it is an input filter on which genuine software filters are based (linear, robust, and other filters). The primary goal of the first RC filters, which consisted of resistors and capacitors, was to eliminate major fluctuations of the output signal and to enable the surface profile to be indicated or displayed correctly. Eventually, computers with analogue/digital cards began to be employed for evaluating data from contour measuring machines. Later, the $2 \mathrm{RC}$ filter for modifying the surface profile was included in standards as a double analogue RC filter with separate links. The drawback of this type of filters is the distortion in the transmission function, mainly due to phase shift (see Fig. 4). 

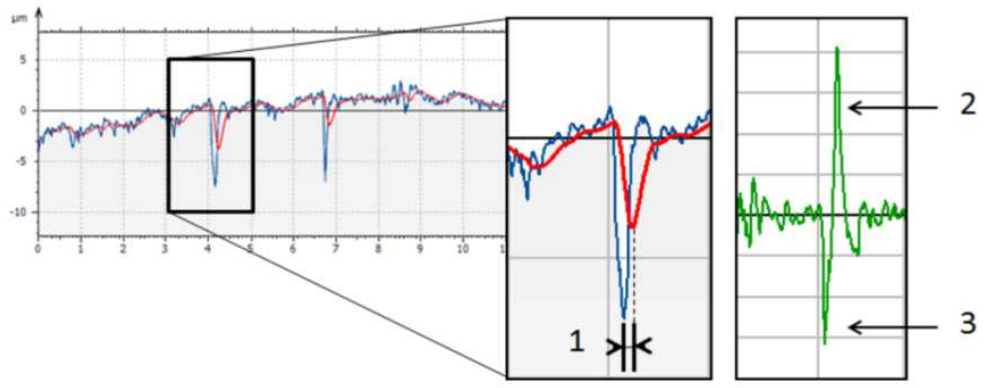

Fig. 4. Profile plot from 2 RC filter

These are the most common filters in roughness measurement applications. They have appropriate transmission characteristics (a1,2/a0) and the percent transmission $(\alpha)$ is easy to determine for any wavelength chosen $(\lambda c)$. In many cases, e.g. with surfaces produced by a sequence of different methods, linear profile filters exhibit undesirable side effects [2-4]. The fundamental specification of this filter differs for open and closed profiles. In order to fully specify this type of filter, one has to know the following equations:

- weighting function,

- transmission characteristics for long and short waves.

Open profile

Weighting function

$$
s(x)=\frac{1}{\propto x \lambda_{c}} e^{\left[-\pi\left(\frac{x}{\alpha x \lambda_{c}}\right)\right]^{2}}
$$

$\mathrm{x}$...distance from the centre of the weighting function

$\lambda c$...cut-off wavelength

$\alpha \ldots$...constant $(0.4697)$

Transmission characteristic - long waves

$$
\frac{a_{1}}{a_{0}}=e^{\left[-\pi\left(\frac{\alpha x \lambda_{c}}{\lambda}\right)\right]^{2}}
$$

$\underline{\text { Transmission characteristic - short waves }}$

$$
\frac{a_{2}}{a_{0}}=1-e^{\left[-\pi\left(\frac{\alpha x \lambda_{c}}{\lambda}\right)\right]^{2}}
$$

\section{Closed profile}

Weighting function

$$
s(x)=\frac{f_{c}}{\propto x L} e^{\left[-\pi\left(\frac{x \times f_{c}}{\alpha x L}\right)\right]^{2}}
$$

$\mathrm{x} .$. distance from the centre of the weighting function

fc...cut-off frequency in the wave

L...length of the closed profile

$\alpha$...constant (0.4697)

Transmission characteristic - long waves

$$
\frac{a_{1}}{a_{0}}=e^{\left[-\pi\left(\frac{\alpha x f}{f_{c}}\right)\right]^{2}}
$$

$\underline{\text { Transmission characteristic - short waves }}$

$$
\frac{a_{2}}{a_{0}}=1-e^{\left[-\pi\left(\frac{\alpha x f}{f_{c}}\right)\right]^{2}}
$$

According to the fundamental principle of these filters, the filtered profile is obtained by subtracting the filter mean line from the primary profile. A nonlinear 
version of a filter which is „robust” in the presence of sharp peaks and deep valleys is a more suitable filtering solution. This means that the filter mean line is less sensitive to the shape of the surface profile. Robust filters are applicable to surfaces characterized by sharp peaks and deep valleys, such as honed surfaces or surfaces produced by casting or sintering. They rely on repetition by which the weighting (evaluation) function is adjusted effectively in the region of surface deviations. As a result, the filter mean line is much less sensitive to surface profiles that consist of sharp peaks and deep valleys. Robust filters are predominantly used for stratified surfaces and for representing shapes, grooves or pores.

The initial step in the use of this filter is the same as with the other roughness filters in step 1 (see Fig. 5): the profile is taken using the ordinary procedure and its mean line is identified. In step 2 (see Fig. 5), the cut-off filter with the max. value of $0.8 \mathrm{k}$ filters out the values above/below this value. In step 3 (see Fig. 5), the final mean line of the profile is identified which is then used for subsequent calculations. In step 4 (see Fig. 5), the filtered-out values mentioned in step 2 are returned. The next processing steps are identical to those used with linear profile filters [3].

Morphological filters involve two morphological operations: dilation (elongation, extension) and erosion (wear, abrasion) which affect the size of surface texture features. Various combinations of both operations alter the characteristics of the surface, and the morphological filter generates either upper or lower envelope of the surface. Morphological filters are used for levelling the surface with respect to the envelope (Fig. 6) [4].
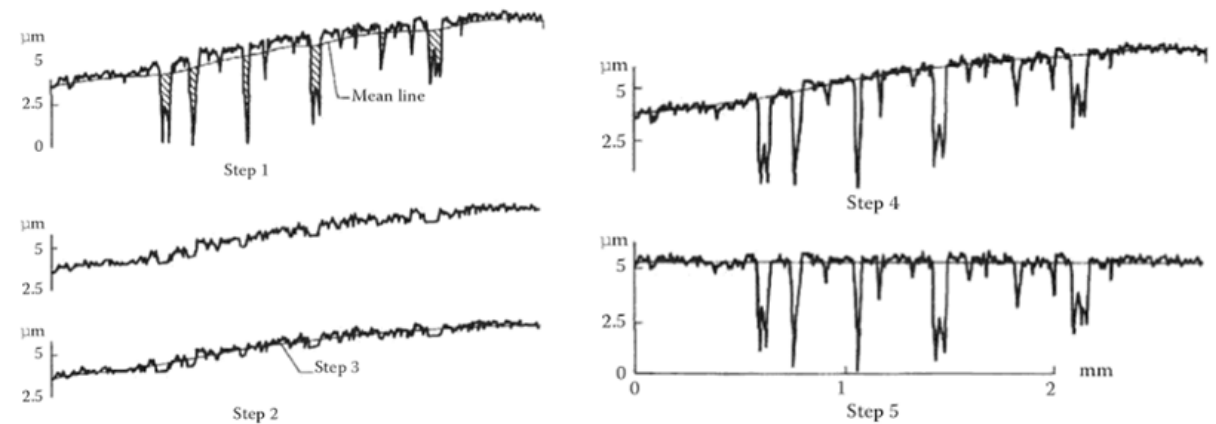

Fig. 5. Principle of data filtering using robust filters

Morphological filters apply offset to the input geometric entities. In general, signal processing deals with both continuous (analogue) and discrete (digital) signals. Recently, there has been a greater interest in discrete morphological filters $[4,6,10]$. In discrete morphological filters, the signal is represented by a finitesize vector. Algorithms have been developed for generating round and flat structuring elements, and for four basic operations (dilation, erosion, opening and clos- 
ing) which yields 8 filtering options altogether. These algorithms are very robust as well because only the calculations involved are shifted (by sequence indexing), added and compared. This demonstrates that digital morphological filters are calculable and that the algorithms can compete with the Gaussian filtering algorithm $[1,4,8]$.

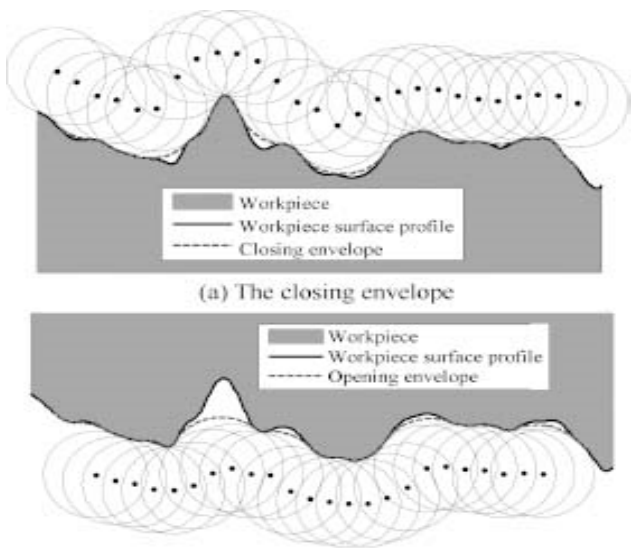

(b) The opening envelope
Fig. 6. Cover profile

\section{Conclusion}

Measurement and evaluation of surface texture represent a major qualitative advance in recent years. Leading producers of measuring instruments (Hommel, Carl Zeiss, and others) respond new requirements. The evolution of measuring instruments is determined by the technical needs of their users as well as by their financial strength. Surface texture is frequently checked by means of single-purpose measuring instruments. For this reason, some of the key producers who put pressure on developing standards related to evaluating the quality of measurement of machined surfaces are the manufacturers of such instruments themselves.

This article aims to point out the issue of data filtering, and thus shed light on the problems with reproducibility of measurement of surface integrity parameters on a single part in two metrology laboratories with equivalent equipment. Once the results were delivered, an offset between the profile curves became apparent. Although the same part had been measured using laboratory surface roughness testers of the same type, Hommel Etamic T800, the results for preselected roughness parameters were different. The cause of the difference was reported to be the choice of different software filters and their settings.

\section{Acknowledgment}

This paper was createdwithin the project GA ZCU v Plzni: SGS-2016-005 „Research and development for innovation in field of Manufacturing processes Technology of metal cutting II". 


\section{References}

[1] ČSN EN ISO 13565-2. Geometrical product specification (GPS) - Surface structure: Profile method - Terms, definitions and surface texture parameters - Part 2: Výškové charakteristiky využívající křivku lineárního poměru materiálu 1. Brussels: CEN, 1999.

[2] ČSN EN ISO 16610-20. Geometrical product specifications (GPS) - Filtration - Part 20: Linear profile filters: Basic concepts. Brussels: ÚNMZ, 2015.

[3] ČSN ISO/TS 16610-21 Geometrical product specifications (GPS) - Filtration - Part 21: Linear profile filters: Gauss filters. Brussels: ÚNMZ, May 2012.

[4] ČSN EN ISO 16610-40. Geometrical product specification (GPS) - Filtration - Part 40: Morphological profile filter: Basic concepts, 2016.

[5] ČSN EN ISO 4287. Geometrical product specification (GPS) - Surface structure: Profile method - Terms, definitions and surface texture parameters - Part 1; Brussels: CEN, 1999.

[6] Gura T.: Determination of acceptable uncertainties of the filters used in the area metrology, Diploma theasis, ČVÚT, Praha 2015.

[7] http://www.hommel-etamic.cz/cz/technicke-informace/drsnost-povrchu-dle-din-eniso/ [online] (27.08.2016).

[8] http://www.techno-mat.cz/data/katedry/kom/KOM_MM_PR_10_CZE_Karasek _Geometricke_vlastnosti_povrchu.pdf [online] (01.02.2015).

[9] ISO/TS 16610-1 Technical specification ISO/TS 16610. Geometrical product specifications (GPS) - Filtration, 2015.

[10] ISO/TS 16610-30:2009. Geometrical product specifications (GPS) - Filtration - Part 30: Robust profile filters: Basic concepts, Geneva, Ed 1, March 2009.

\section{FILTRY PROGRAMOWE CHROPOWATOŚCI POWIERZCHNI}

\section{Streszczen ie}

Celem artykułu jest przedstawienie systemu pomiaru chropowatości, w szczególności problemu filtrowania i przetwarzania wyników. Na początku tego artykułu zdefiniowano trzy podstawowe parametry powierzchni: chropowatość, falistość i kształt powierzchni. Podczas pomiaru chropowatości te trzy parametry są skanowane razem, a na etapie oceny konieczne jest ich oddzielenie. Filtracja jest możliwa za pomocą urządzeń do pomiaru chropowatości i filtrów programowych. Następna część artykułu koncentruje się na omówieniu problemów związanych z filtrowaniem sprzętowym tych trzech parametrów powierzchni. Wyjaśnienie filtrowania programowego danych oprogramowania następuje po omówieniu filtrowania sprzętowego. Opis filtrów programowych zawiera podstawową matematyczną definicję filtrów, ich obszar użytkowania oraz ograniczenia.

Słowa kluczowe: chropowatość, falistość i kształt pola powierzchni, filtry sprzętowe i programowe

DOI: $10.7862 / \mathrm{rm} .2017 .29$

Otrzymano/received:10.06.2017

Zaakceptowano/accepted: 11.09.2017 
